
\title{
$\beta$-Blockade for Patients with Hypertension, Ischemic Heart Disease or Heart Failure: Where are We Now?
}

\author{
Atul Pathak' \\ Sanaa Mrabeti ${ }^{2}$ \\ 'Department of Cardiovascular Medicine, \\ Centre Hospitalier Princesse Grace, \\ Monaco; ${ }^{2}$ Medical Affairs EMEA, Merck \\ Serono Middle East FZ-LLC, Dubai, \\ United Arab Emirates
}

\begin{abstract}
: $\beta$-blockers are a heterogeneous class of drugs, with varying selectivity/specificity for $\beta_{1}$ vs $\beta_{2}$ receptors, intrinsic sympathomimetic activity (ISA), and vasodilatory properties (through $\beta_{2}$ stimulation, $\alpha$ receptor blockade or nitric oxide release). These drugs are indicated for the management of arterial hypertension, heart failure or ischemic heart disease (IHD; eg angina pectoris or prior myocardial infarction). Most of the benefit of $\beta$-blockade in these conditions arises from blockade of the $\beta_{1}$ receptor, and, in practice, the addition of ISA appears to reduce the potential for improved clinical outcomes in people with heart failure or IHD. Aspects of the benefit/risk balance of $\beta$-blockers remain controversial, and recent meta-analyses have shed new light on this issue. We have reviewed the current place of cardioselective $\beta$-blockade in hypertension, IHD and heart failure, with special reference to the therapeutic profile of a highly selective $\beta_{1}$-adrenoceptor blocker, bisoprolol.
\end{abstract}

Keywords: beta blockade, hypertension, congestive heart failure, ischemic heart disease, bisoprolol

\section{Introduction}

The $\beta$-blockers are a heterogeneous class of therapeutic agents. Individual drugs have differing selectivity for $\beta_{1}$ or $\beta_{2}$ receptors, some display limited activation of $\beta$ receptors (intrinsic sympathomimetic activity), and some additional effects on $\alpha$ adrenoceptors, or promote release of nitric oxide (NO). ${ }^{1}$ This review sets out to provide a pragmatic approach to understanding the therapeutic benefits and limitations of $\beta$-blockers in people with hypertension, ischemic heart disease (IHD; with or without prior myocardial infarction) or congestive heart failure (CHF) often associated in the same patient.

Hypertension is managed largely in the primary care setting, while treatment for IHD or CHF is often initiated by a cardiologist. Nevertheless, the need for long-term treatment of IHD or CHF means that the primary care physician will have an important role in managing these therapies. It is important, therefore, that physicians are familiar with the initiation and maintenance of $\beta$-blocker therapy, whoever initiated it.

\section{Clinical Relevance of Pharmacologic Differences Between $\beta$-Blockers Interactions with $\beta$ Receptors and Selectivity for $\beta$ Receptor Subtypes}

Most widely-used $\beta$-blockers (metoprolol, carvedilol, propranolol, nebivolol, bisoprolol) are inverse agonists at the $\beta_{1}$-adrenoceptor, meaning that a prevailing (but low)
Correspondence: Atul Pathak

Department of Cardiovascular Medicin

Centre Hospitalier Princesse Grace,

Avenue Pasteur, BP 489 MC, 98012 ,

CEDEX, Principality of Monaco

Email Atul.PATHAK@chpg.mc 
level of basal, constitutive downstream signal transduction from the receptor is reduced by exposure to the drug, even in the absence of a $\beta$ receptor agonist. ${ }^{2}$ Differences in the level of inverse agonism between $\beta$-blockers may affect their pharmacodynamic properties, for example observation more pronounced negative inotropism for metoprolol vs carvedilol. ${ }^{3}$ Biased agonism (where a drug may activate part of a post-receptor signalling cascade) represents another way in which $\beta$-blockers may differ. For example, such a mechanism involving activation of the $\beta$-arrestin pathway has been proposed as a potentially cardioprotective pathway for carvedilol, especially in the setting of $\mathrm{CHF}^{3}$

Individual $\beta$-blockers can also be distinguished from one another on the basis of their selectivity for $\beta_{1}$ vs $\beta_{2}$ receptors, and whether or not they have intrinsic sympathomimetic activity (ISA) directed against $\beta_{1}$ or $\beta_{2}$ receptors (Table 1). Table 2 summarizes briefly the typical clinical impact of these mechanisms. The $\beta_{1}$ blockade component induces changes in cardiac function consistent with reduced oxygen demand (particularly reduced heart rate and contractility). ISA directed against the $\beta_{1}$ receptor tends to limit falls in contractility and heart rate, while agents with additional vasodilatory properties tend to reduce blood pressure without increasing heart rate (although carvedilol reduces heart rate $^{4}$ ) and have less adverse metabolic consequences, compared with selective $\beta_{1}$ receptor blockade.

A pharmacologic study using cloned human $\beta$ receptors showed that bisoprolol was 14-fold selective for $\beta_{1}$ vs $\beta_{2}$ receptors (similar to xamoterol), compared with 4.7-fold for atenolol, 2.4-fold for acebutolol and 2.3-fold for metoprolol. ${ }^{5}$ Non-selective agents may induce some vasoconstriction,

Table I Subclasses of $\beta$-Blockers

\begin{tabular}{|c|c|c|c|}
\hline & & \multicolumn{2}{|c|}{$\beta_{1}$ Receptor Selectivity? } \\
\hline & & Yes & No \\
\hline \multirow[t]{2}{*}{$\begin{array}{l}\text { Intrinsic } \\
\text { sympathomimetic } \\
\text { activity? }\end{array}$} & Yes & $\begin{array}{l}\text { Xamoterol } \\
\text { Acebutolol }^{\mathrm{a}} \\
\text { Celiprolol }^{\mathrm{a}, \mathrm{b}} \\
\text { Nevibolol }^{\mathrm{c}}\end{array}$ & $\begin{array}{l}\text { Pindolol }^{\mathrm{a}} \\
\text { Oxprenolol } \\
\text { Labetolol }^{\mathrm{b}} \\
\text { Bucindolol }^{\mathrm{b}}\end{array}$ \\
\hline & No & $\begin{array}{l}\text { Bisoprolol } \\
\text { Metoprolol } \\
\text { Atenolol } \\
\text { Esmolol }\end{array}$ & $\begin{array}{c}\text { Propranolol } \\
\text { Sotalol } \\
\text { Timolol } \\
\text { Carvedilol }^{\mathrm{b}}\end{array}$ \\
\hline
\end{tabular}

Notes: Additional vasodilation: a ${ }^{2}$ timulates $\beta_{2}$ adrenoceptors; blocks $\alpha$ adrenoceptors; cactivates $\beta_{3}$ receptors. See text for references. with potentially adverse consequences for the peripheral circulation and risk of bronchospasm in at-risk subjects. The presence of $\beta_{2}$ or $\beta_{3}$ receptors in muscle and the pancreas imply possible effects on glucose or lipid metabolism; ${ }^{6}$ unsurprisingly, cardioselective $\beta$-blockers have a smaller effect on glycemia. ${ }^{7}$ Another systematic review and meta-analysis of studies in patients with heart failure treated with a $\beta$-blocker concluded that there was a small excess of hyperglycemia for $\beta$-blocker vs placebo (effect size 1.3 ), but that $83 \%$ of presentations with hyperglycemia were not due to $\beta$-blockade. ${ }^{8}$ There was no difference in general for side-effects in this analysis for selective (bisoprolol, metoprolol, nebivolol) vs non-selective agents (bucindolol, carvedilol). $\beta$-blockade was not associated with risk of new-onset diabetes in the randomized NAVIGATOR diabetes prevention trial, during which $16 \%$ of patients started new $\beta$-blocker therapy. ${ }^{9}$

\section{Selectivity and Metabolic Effects}

$\beta$-blockers may modestly increase triglycerides and decrease HDL-cholesterol, with little effect on LDL-cholesterol, although the presence of high $\beta_{1}$-selectivity has been shown to ameliorate such effects. ${ }^{1,10,11}$ These potential side effects should not present a barrier to the treatment of most patients, especially with a cardioselective drug.

\section{Selectivity and Effects on the Respiratory System}

Use of a $\beta_{1}$-selective agent also reduces the risk of bronchospasm in a patient predisposed to this problem by chronic obstructive pulmonary disease (COPD) or asthma. ${ }^{12,13}$ This class of drugs has been shown to reduce mortality post-myocardial infarction in patients with COPD (this registry study did not tell us which $\beta$-blockers were used, however). ${ }^{14}$ Recent randomized ${ }^{15}$ and observational ${ }^{16}$ studies have suggested that a highly $\beta_{1}$-selective agent (bisoprolol) was better tolerated (fewer side-effects, or CHF and/or COPD exacerbations) than carvedilol in patients with comorbid CHF and COPD. These observations stress the need for individualization of therapy for these complex patients, and highlight the pharmacologic diversity available within the $\beta$-blocker class.

\section{Other Mechanisms of $\beta$-Blockers}

Some $\beta$-blockers demonstrate additional mechanistic properties that may influence their pharmacodynamic properties. For example, labetalol and carvedilol are non-selective $\beta$ blockers that additionally block $\alpha$ adrenoceptors, 
Table 2 Consequences of $\beta$-Adrenoceptor Selectivity and Presence or Absence of ISA

\begin{tabular}{|c|c|}
\hline Property & Typical Clinical Consequence \\
\hline $\begin{array}{l}\text { Selective blockade of } \beta_{1} \\
\text { receptors }\end{array}$ & $\begin{array}{l}\text { Slowed heart rate (chronotropic effect), reduced cardiac contractility, reduced myocardial oxygen } \\
\text { consumption; disturbed glucose metabolism may precipitate hyperglycaemia or new-onset type } 2 \text { diabetes }\end{array}$ \\
\hline $\begin{array}{l}\text { Additional blockade of } \beta_{2} \\
\text { receptors }\end{array}$ & $\begin{array}{l}\text { Smooth muscle contraction (vasculature and airways) can cause cold extremities and bronchospasm in at-risk } \\
\text { patients; potential for metabolic disturbance, as above }\end{array}$ \\
\hline $\begin{array}{l}\text { Additional stimulation of } \beta_{1} \\
\text { receptors (ISA) }\end{array}$ & $\begin{array}{l}\text { Less resting bradycardia, less reduction in cardiac output, less potentially adverse metabolic effects during long- } \\
\text { term treatment vs } \beta_{1} \text {-selective agents }\end{array}$ \\
\hline $\begin{array}{l}\text { Additional stimulation of } \beta_{2} \\
\text { receptors (ISA) }\end{array}$ & Additional vasodilation: can reduce blood pressure with limited effect on heart rate vs $\beta_{1}$-selective agents \\
\hline $\begin{array}{l}\text { Additional vasodilatory } \\
\text { properties }\end{array}$ & $\begin{array}{l}\text { Additional stimulation of } \alpha_{1} \text { receptors or enhanced nitric oxide release can reduce blood pressure with limited } \\
\text { effect on heart rate vs } \beta_{1} \text {-selective agents; less potentially adverse metabolic effects during long-term treatment } \\
\text { vs } \beta_{1} \text {-selective agents }\end{array}$ \\
\hline
\end{tabular}

Note: See text for references. Abbreviations: ISA, intrinsic sympathomimetic activity.

theoretically with potential for greater suppression of sympathetic activation and greater vasodilation. ${ }^{17}$ Nebivolol activates $\beta^{3}$-adrenoceptors in addition to its selective $\beta_{1}$ - vs $\beta_{2}$ blockade, which increases production of nitric oxide, another vasodilatory mechanism. ${ }^{18}$ The degree of lipophilicity of a $\beta$-blocker may also influence its pharmacologic properties, in terms of penetration of the central nervous system, metabolism/excretion and pharmacokinetics (in general, lipophilic agents tend to have greater pharmacokinetic variability and a greater tendency to drug interactions). ${ }^{19}$ Pindolol, propranolol, timolol, and metoprolol are highly lipophilic; bisoprolol, acebutolol, carvedilol and nebivolol are moderately lipophilic; and atenolol, labetalol and nadolol demonstrate low lipophilicity. ${ }^{19}$

\section{Under use of $\beta$-Blockers in Patients with Comorbidities}

Clinical experience shows that prescription of a $\beta$-blocker improves prognosis in patients with comorbid COPD and cardiovascular conditions. ${ }^{19}$ Studies have suggested underprescribing of $\beta$-blockers in patients with comorbid conditions, such as COPD or diabetes, however. ${ }^{20,21}$

\section{$\beta$-Blockade in the Management of Chronic Congestive Heart Failure Overview of the Evidence Base}

Randomized, controlled trials have evaluated the potential for $\beta$-blockade to improve outcomes in people with $\mathrm{CHF}^{22,23}$ and principal outcome trials in this area are summarized in
Table 3. ${ }^{24-31}$ The initial, underpowered Cardiac Insufficiency Bisoprolol Study (CIBIS) trial demonstrated some symptomatic improvements, but not significant outcome benefits. ${ }^{24}$ The larger CIBIS II trial demonstrated a significant outcomes benefit for bisoprolol vs placebo. ${ }^{25}$ CIBIS III demonstrated similar outcomes following initiation of therapy with bisoprolol or ACE inhibitor, with both used in combination later. ${ }^{26}$ Significant improvements in mortality were also seen in placebo-controlled outcome trials with metoprolol (selective $\beta_{1}$-blocker), ${ }^{27}$ nebivolol (selective $\beta_{1}$-blocker with additional vasodilating properties), ${ }^{28}$ and carvedilol (nonselective $\beta$-blocker with additional $\alpha$ blockade). ${ }^{30,31} \mathrm{~A}$ nonselective $\beta$-blocker with ISA did not influence cardiovascular outcomes significantly, compared with placebo). ${ }^{29}$

Meta-analyses provide insight into the overall effects of $\beta$-blockers in populations with CHF. One recent metaanalysis of 21 randomized trials in a total of 5849 patients with $\mathrm{CHF}$ demonstrated relative risk reductions for $\beta$ blockade vs placebo of $-29 \%$ for overall mortality, $-29 \%$ for cardiovascular mortality, $-34 \%$ for death from pump failure, and $-30 \%$ for sudden death. ${ }^{32}$ All of these risk reductions were statistically significant. Other metaanalyses support comparable outcome benefits from the use of $\beta$-blockers in $\mathrm{CHF}^{23,33}$

The analyses discussed above relate almost exclusively to patients with reduced left ventricular ejection fraction (HFrEF). Importantly, the outcome benefits from $\beta$ blockade in HFrEF are seen in all age groups and in both genders. ${ }^{34}$ An editorial accompanying this publication notes that older patients and women have been under- 
Table 3 Principal Randomized Outcome Trials of $\beta$-Blockers with Varying Selectivity Profiles in Patients with CHF or Ischaemic Heart Disease

\begin{tabular}{|c|c|c|c|}
\hline Trial & Patients & Randomized Treatments & Main Findings \\
\hline \multicolumn{4}{|c|}{ Selective $\beta_{1}$ adrenoceptor blockers } \\
\hline $\begin{array}{l}\mathrm{CIBIS}^{24} \\
\text { (bisoprolol) }\end{array}$ & $\begin{array}{l}64 \text { I patients with CHF of various } \\
\text { etiology and NYHA class III-IV; all } \\
\text { had LVEF }<40 \%\end{array}$ & $\begin{array}{l}\text { Bisoprolol vs placebo added to usual } \\
\text { care (diuretic and vasodilator, } 90 \% \\
\text { received ACE inhibitor) }\end{array}$ & $\begin{array}{l}\text { Fewer hospitalizations for CHF decompensation } \\
\text { on bisoprolol, but no significant differences } \\
\text { between groups for mortality outcomes }\end{array}$ \\
\hline $\begin{array}{l}\text { CIBIS } I^{25} \\
\text { (bisoprolol) }\end{array}$ & $\begin{array}{l}2647 \text { patients with NHYA class } \\
\text { III-IV CHF and LVEF } \leq 35\end{array}$ & $\begin{array}{l}\text { Bisoprolol vs placebo added to } \\
\text { background therapy of diuretics and } \\
\text { ACE inhibitor }\end{array}$ & $\begin{array}{l}\text { Stopped early due to significant mortality } \\
\text { benefit on bisoprolol on interim analysis (HR } \\
0.66[95 \% \mathrm{Cl} 0.54 \text { to } 0.8 \mathrm{I}], \mathrm{p}<0.000 \mathrm{I} \text { ); also } \\
\text { benefit for fewer sudden deaths on bisoprolol } \\
\text { (HR } 0.56[0.39 \text { to } 0.80], \mathrm{p}=0.00 \mathrm{II} \text { ) }\end{array}$ \\
\hline $\begin{array}{l}\text { CIBIS III' } \\
\text { (bisoprolol) }\end{array}$ & $\begin{array}{l}\text { I0I0 patients with mild-to } \\
\text { moderate CHF and LVEF } \leq 35 \text {; } \\
\text { naïve to } \beta \text {-blockers or RAS } \\
\text { blocker treatment }\end{array}$ & $\begin{array}{l}\text { Bisoprolol or ACE inhibitor for } 6 \\
\text { months followed by both in } \\
\text { combination for } 6-24 \text { months }\end{array}$ & $\begin{array}{l}\text { Clinical outcomes were similar for the } \\
\text { bisoprolol-first and enalapril-first groups }\end{array}$ \\
\hline $\begin{array}{l}\text { MERIT-HF }{ }^{27} \\
\text { (metoprolol) }\end{array}$ & $\begin{array}{l}399 \text { I patients with mild-to- } \\
\text { moderate CHF }\end{array}$ & $\begin{array}{l}\text { QD Metoprolol CR/XL I2.5 mg } \\
\text { (NYHA III-IV) or } 25.0 \mathrm{mg}(\mathrm{NYHA} \text { II) } \\
\text { for I year }\end{array}$ & $\begin{array}{l}34 \% \text { relative risk reduction in all-cause death in } \\
\text { favour of metoprolol; also reductions in sudden } \\
\text { death (by } 41 \% \text { ) and death from worsening } \mathrm{CHF} \\
\text { (by } 49 \% \text { ) }\end{array}$ \\
\hline \multicolumn{4}{|c|}{ Selective $\beta_{1}$-adrenoceptor blockers with additional vasodilator properties } \\
\hline $\begin{array}{l}\text { SENIORS } \\
\text { (nebivolol) }\end{array}$ & $2 / 28$ patients with LVEF $\leq 35 \%$ & Nebivolol or placebo for 21 months. & $\begin{array}{l}\text { Reduced risk of primary composite (CV death } \\
\text { or hospitalization) in favour of nebivolol }(-14 \%)\end{array}$ \\
\hline \multicolumn{4}{|c|}{ Non-selective $\beta$-blocker with intrinsic sympathomimetic activity } \\
\hline $\begin{array}{l}\mathrm{BEST}^{29} \\
\text { (bucindolol) }\end{array}$ & $\begin{array}{l}2708 \text { patients with HYHA III-IV) } \\
\text { CHF }\end{array}$ & Bucindolol or placebo for 2 years & $\begin{array}{l}\text { No significant effect on mortality (primary } \\
\text { endpoint); modest reductions with bucindolol in } \\
\text { secondary endpoints, eg CV death }(-14 \%) \text { or } \\
\text { transplantation or CV death }(-14 \%)\end{array}$ \\
\hline \multicolumn{4}{|c|}{ Non-selective $\beta$-blocker with additional $\alpha$-blockade } \\
\hline $\begin{array}{l}\text { US Carvedilol } \\
\text { Heart Failure } \\
\text { Study Group } \\
\text { (carvedilol) }\end{array}$ & $\begin{array}{l}\text { I094 patients with mild, } \\
\text { moderate or severe CHF }\end{array}$ & $\begin{array}{l}\text { Carvedilol } 6.25-50 \mathrm{mg} \text { BID } \\
\text { (depending on CHF severity) or } \\
\text { placebo, for } 6 \mathrm{mo} \text { ( } 12 \text { mo for patients } \\
\text { with mild CHF) }\end{array}$ & $\begin{array}{l}65 \% \text { relative risk reduction in mortality in favour } \\
\text { of carvedilol in the overall population; also } 27 \% \\
\text { reduction in risk of CV hospitalization and } 38 \% \\
\text { reduction in hospitalization or CV death }\end{array}$ \\
\hline $\begin{array}{l}\text { COPERNICUS }^{31} \\
\text { (carvedilol) }\end{array}$ & 2289 patients with severe CHF & $\begin{array}{l}\text { Carvedilol (target dose } 25 \mathrm{mg} \text { BID) } \\
\text { or placebo for } 10.4 \mathrm{mo}\end{array}$ & $\begin{array}{l}35 \% \text { relative risk reduction for death in favour } \\
\text { of carvedilol; also } 24 \% \text { reduction in risk of } \\
\text { hospitalization or death }\end{array}$ \\
\hline
\end{tabular}

Notes: All risk reductions shown were statistically significant. Follow-up times are averages.

Abbreviations: CHF, congestive heart failure; LVEF, left ventricular ejection fraction; NYHA, New York Heart Association.

represented in randomized CHF trials, leading to suggestions of reduced benefit in these groups. ${ }^{35}$ Meta-analyses support the use of $\beta$-blockers where indicated, irrespective of age and gender.

There is no randomized outcomes trial of $\beta$-blockade in patients with CHF with preserved left ventricular ejection fraction (HFpEF). A study from the OPTIMIZE-HF registry demonstrated reduced mortality with high-dose $\beta$-blockade (vs no $\beta$-blockade) in patients with $\mathrm{HFpEF}$ and heart rate $\geq 70$ bpm. ${ }^{36}$ A meta-analysis demonstrated reduced mortality with $\beta$-blockade in patients with HFpEF (relative risk 0.78 [95\% CI 0.65 to 0.94 ], $p=0.008$ ), with no significant effect of other treatments, including ACE inhibitors, mineralocorticoid antagonists and aldosterone antagonists. ${ }^{37}$ Another patientlevel meta-analysis found reduced mortality with $\beta$-blocker s for patients with LVEF $<40 \%$ or $40-49 \%$, but with no effect 
for patients with LVEF $\geq 50 \% .{ }^{38}$ Other data suggest adverse effects of $\beta$-blockers in this population, however. ${ }^{39}$ Further research will be needed before these studies translate into guideline recommendations for the management of $\mathrm{HFpEF}$ (see below).

\section{Are There Clinically Relevant Differences Between Individual $\beta$-Blockers or Subtypes of $\beta$-Blockers with Regard to Management of CHF?}

Interestingly, one meta-analysis described above included a comparison between individual agents (and placebo, each added to standard care), as well as for all trials combined..$^{33}$ Randomization to placebo was associated with higher risk of the main outcome of mortality, while there were no clear or significant differences between bisoprolol and other agents. The magnitude of the effect of bisoprolol on secondary cardiovascular outcomes was comparable to that seen in the overall pooled analysis; however, it was not statistically significant, presumably due to the reduced number of patients in the analysis.

Six available large evaluations of $\beta$-blockers were used in another meta-analysis to investigate the contribution of ISA to effects on outcomes in patient populations treated with $\beta$-blockers plus an ACE inhibitor. ${ }^{1}$ For $\beta$-blockers without ISA, reductions in all-cause mortality vs placebo were $-34 \%$ for bisoprolol, $-34 \%$ for metoprolol and $-35 \%$ for carvedilol. In contrast, among $\beta$-blockers with ISA, bucindolol did not reduce mortality significantly while xamoterol more than doubled the mortality rate in people with severe disease. Also, this analysis is complicated somewhat by the inclusion of $\beta$-blockers with additional vasodilatory mechanisms (bucindolol, nebivolol and carvedilol; see Table 1). ${ }^{32}$ One randomized comparison of the $\beta_{1}$-selective agents xamoterol (ISA) and metoprolol (no ISA) revealed no significant extra benefits associated with ISA for endpoints such as exercise time, quality of life and NYHA classification, casting further doubt on additional benefits from ISA in patients with heart failure. $^{40}$

\section{What the Guidelines Say}

The place of $\beta$-blockade (alongside ACE inhibition) in the management of CHF is well-established and supported by influential guidelines (Table 4). ${ }^{41,42}$ The US guideline stresses the use of "evidence-based" $\beta$-blockers, identified as bisoprolol, metoprolol and carvedilol. European guidelines emphasize the utility of co-prescribing a $\beta$-blocker and a RAS blocker at the diagnosis of stable symptomatic CHF.

Take-Home Messages: $\beta$-Blockers in CHF Management

The use of $\beta$-blockers in patients with stable, symptomatic CHF is supported by randomized, placebo-controlled outcome trials and by major international guidelines, as described above. The use of a highly cardioselective agent may help to reduce the incidence of side-effects due to blockade of other $\beta$ receptor subtypes during titration to the optimal (ie maximally tolerated) dose within the drug's labelling. The addition of ISA does not add additional outcome benefits to cardioselective $\beta$-blockade in CHF. No large, randomized trial has demonstrated superiority on mortality or other outcomes for $\beta$-blockers with additional vasodilatory mechanisms, compared with cardioselective $\beta$-blockade alone. $\beta$-blockers remain underprescribed, especially in patients with comorbidities such as COPD or diabetes.

\section{$\beta$-Blockade in the Management of Ischemic Heart Disease: \\ Overview of the Evidence Base}

$\beta$-blocker therapy reduces mortality post-MI, with larger effects observed in longer-term trials compared with shorterterm trials. ${ }^{43}$ Most of the pivotal evaluations of $\beta$-blockers were conducted more than two decades ago, however, and usual-care treatment for myocardial ischemia has changed since that time. ${ }^{44}$

A large meta-analysis of observational studies (26 trials, $\mathrm{N}=863,335$ ) was conducted in patients with IHD who also received the more modern intervention of percutaneous revascularization. ${ }^{45}$ This analysis found a reduction in the risk of mortality for patients taking vs not taking $\beta$-blocker therapy (OR 0.69 [0.66 to 0.72$]$ ). Importantly, subgroup analyses from this large dataset found benefit irrespective of the nature of the IHD (acute coronary syndrome [ACS] or chronic stable angina), or LVEF. The magnitude of benefit increased as the duration of treatment increased. More randomized evaluations of $\beta$-blockade, added to the current standard of care for CHF, are needed. ${ }^{44}$

Other clinical trials and meta-analyses have demonstrated the benefit of starting $\beta$-blocker therapy early after acute MI. ${ }^{45,46}$ One such study showed that starting 
Table 4 Summary of Principal International Guideline Recommendations for the Use of $\beta$-Blockers in the USA and Europe

\begin{tabular}{|c|c|c|}
\hline & USA (AHA and Other Expert Societies) & Europe (ESC) \\
\hline Heart failure ${ }^{41,42}$ & $\begin{array}{l}\text { Use "evidence-based } \beta \text {-blocker" (bisoprolol, metoprolol, } \\
\text { carvedilol) with RAS inhibitor (+diuretic as needed) for CHF } \\
\text { with reduced ejection fraction }\end{array}$ & $\begin{array}{l}\text { Start together with ACE inhibitor as soon as CHF is } \\
\text { diagnosed } \\
\text { Initiate at low dose when CHF with reduced ejection } \\
\text { fraction is stable; then titrate the dosage slowly } \\
\text { Consider use to control heart rate in patients with AF } \\
\text { and high heart rate }\end{array}$ \\
\hline IHD or $\mathbf{A C S}^{53-56}$ & $\begin{array}{l}\text { Recommended first-line for post-MI with sustained LV systolic } \\
\text { function, required (if not contraindicated) for reduced LV } \\
\text { systolic function } \\
\text { Intravenous treatment on presentation post-MI with } \\
\text { refractory hypertension or continuing ischemia } \\
\text { Initiate long-term oral treatment with } \beta \text {-blocker within the } \\
\text { first } 24 \text { hours after onset of ACS (specifically use evidence- } \\
\text { based } \beta \text {-blocker [bisoprolol, carvedilol, metoprolol) for } \\
\text { NSTEMI } \\
\text { Continue during and after hospitalization } \\
\text { Where stablilized heart failure is present, use an evidence- } \\
\text { based agent (carvedilol, metoprolol or bisoprolol) }\end{array}$ & $\begin{array}{l}\text { Recommended for use in patients with prior MI and } \\
\text { asymptomatic LV dysfunction } \\
\text { Included in first-line options for patients with chronic } \\
\text { IHD, except for patients with low heart rate } \\
\text { Intravenous treatment at presentation with STEMI } \\
\text { Initiate long-term oral treatment within the first } 24 \text { hours } \\
\text { after STEMI } \\
\text { Initiate early for NSTEMI with continuing symptoms of } \\
\text { ischemia }\end{array}$ \\
\hline Hypertension $^{12,13}$ & $\begin{array}{l}\text { Not included among preferred agents for initiation of } \\
\text { antihypertensive therapy unless IHD of CHF is present } \\
\text { Bisoprolol and metoprolol are preferred cardioselective } \beta \text { - } \\
\text { blockers for hypertensive patients with HFrEF } \\
\text { Cardediliol preferred over labetalol for } \beta \text {-blockers with } \alpha_{1} \text { - } \\
\text { adrenoceptor agonist activity } \\
\text { Cardioselective agents preferred for patients with } \\
\text { bronchospastic airway disease }\end{array}$ & $\begin{array}{l}\text { Included among preferred agents for initiation of } \\
\text { antihypertensive therapy, based on similar outcome } \\
\text { benefits in recent meta-analyses } \\
\beta \text {-blockers are among preferred agents for IHD or CHF, } \\
\text { or for pregnant women } \\
\text { Contraindicated in asthma, high grade sinoatrial or } \\
\text { atrioventricular block or bradycardia ( }<60 \text { bpm) } \\
\text { Caution in metabolic syndrome, glucose intolerance, } \\
\text { athletes/physically active } \\
\text { Include with RAS blocker in regimens for hypertensive } \\
\text { patients with prior MI (see above) }\end{array}$ \\
\hline
\end{tabular}

Note: All recommendations are for patients without contraindications to $\beta$-blockade.

Abbreviations: ACS, acute coronary syndrome; AHA, American Heart Association; CHF, congestive heart failure; ESC, European Society of Cardiology; HFrEF, heart failure with reduced left ventricular ejection fraction; IHD, ischemic heart disease; LV, left ventricular; NSTEMI, non-ST elevation myocardial infarction; STEMI, ST elevation myocardial infarction; RAS, renin-angiotensin system.

a $\beta$-blocker within one year of MI reduced mortality significantly, with no significant effect on mortality from starting treatment at later time points. ${ }^{47}$ The same analysis found that prescription of a calcium channel blocker at any time point did not reduce mortality risk. A small (but randomized) study in 330 patients with coronary artery disease suggested a reduced 1-year incidence of a composite cardiovascular outcome for patients receiving selective $\beta_{1}$-blockade (bisoprolol) vs a short-active calcium channel blocker (nifedipine). ${ }^{48,49}$ Outcome benefits with $\beta$-blockade are additive to those from an ACE inhibitor in patients with cardiovascular disease, according to a pooled analysis of three outcome trials. ${ }^{50}$

\section{Are There Clinically Relevant Differences Between Individual $\beta$-Blockers or Subtypes of $\beta$-Blockers with Regard to Management of IHD?}

A retrospective study of $>200,000$ patients with prior MI found little difference in mortality between $\beta_{1}$-selective (atenolol, metoprolol) or non-selective (propranolol) $\beta$-blockers. ${ }^{43}$ A meta-analysis supported these findings, and also demonstrated less mortality benefit post-MI for $\beta$-blockers with vs without ISA, consistent with experience in heart failure, as described above. ${ }^{43}$ Indeed, the US guideline for the management of non-ST elevation MI recommends the use of one of three $\beta$-blockers without ISA (carvedilol, metoprolol or biso- 
prolol). In addition, a large registry study found no difference in 8-month mortality between carvedilol and pooled data from three $\beta_{1}$-selective agents (bisoprolol, metoprolol, nebivolol) among patients who underwent coronary revascularization for acute MI. ${ }^{51}$ These data suggest limited benefit for additional vasodilator properties.

\section{What the Guidelines Say}

Once again, outcome benefits with $\beta$-blockade for patients with prior MI are proven beyond doubt, and major guidelines recommend that this treatment is given early in the absence of contraindications such as acute heart failure or risk of cardiogenic shock, etc. (Table 4). ${ }^{12,13,41,42,52-57}$ Influential guidelines recommend $\beta$-blockade as first-line therapy for stable coronary artery disease (Table 4). ${ }^{32,33}$ All guidelines recommend appropriate anti-ischemic treatment, or treatment to reduce the risk of subsequent MI, such as RAS blockers, antiplatelet agents, statins, anticoagulants, etc., for defined subtypes of patients.

It has been assumed that the dose of a $\beta$-blocker should be titrated to the levels used in randomized outcome trials to ensure effective secondary prevention of MI. For example, an expert review from the UK recommended that

a cardioselective beta-blocker (for example, bisoprolol) should be commenced in all patients once hemodynamically stable and up-titrated to a maximum tolerated dose. ${ }^{58}$

However, recent registry data suggested that the dose level achieved for $\beta$-blocker therapy had only limited impact on mortality post-acute MI, with all $\beta$-blocker doses associated with improved survival relative to no $\beta$-blockade. ${ }^{59}$ Reduced heart rate is associated with improved prognosis in patients with heart failure. ${ }^{60}$ ESC guidelines for the management of chronic IHD include a target for resting heart rate of 55-60 bpm, ${ }^{57}$ and US guidelines have recommended a target for heart rate of 50-60 bpm in these patients. $^{61}$ The ESC guideline recommends use of lowdose $\beta$-blockade (or a non-dihydropyridine calcium channel blocker) in patients with low blood pressure. ${ }^{57}$

\section{Take-Home Messages: $\beta$-Blockers in IHD Management}

The benefits of $\beta$-blockade post-acute MI are clear, as for the management of $\mathrm{CHF}$, described above. Clinical evidence and guideline recommendations favour early application of $\beta$-blockers after MI, where patients are hemodynamically stable, as this approach appears to have greater long-term outcome benefits. How long to continue $\beta$-blocker therapy, and what dose to aim for, remain areas of controversy. The registry study that found outcome benefits for any dose of $\beta$-blocker compared with no $\beta$-blocker in a post-MI population is especially interesting. These data suggest that any tolerated $\beta$-blocker dose is likely to be of benefit for this population, within individualized care for a patient with prior MI with the use of higher doses limited by side-effects, especially if a clinically significant reduction in heart rate is achieved. ${ }^{56,58,60}$

\section{$\beta$-Blockade in the Management of Hypertension}

\section{Rationale and Overview of the Evidence Base}

Meta-analyses show that treatment with a $\beta$-blocker reduces the risk of adverse cardiovascular outcomes relative to placebo in people with hypertension. ${ }^{62,63}$ Some meta-analyses suggested that the effect on cardiovascular outcomes was modest considering the reductions of blood pressure achieved, and inferior to that seen with other antihypertensive classes (particularly stroke), although the heterogeneity of $\beta$-blockers as a therapeutic class may have hindered effective meta-analysis. ${ }^{62-66}$

A more recent and very large meta-analysis (147 trials incorporating 464,000 patients with hypertension) found that $\beta$-blockade reduced CHD events by $11 \%$ and stroke events by $19 \%$, vs placebo (trials of $\beta$-blockade for reduction of IHD events in patients with a history of this condition were excluded from this analysis). ${ }^{67}$ These risk reductions were similar to those achieved by use of other classes of antihypertensive agents. The efficacy of $\beta$-blockers for preventing CHD events in patients with hypertension (with or without cardiovascular disease) depended largely on the blood pressure reduction achieved (apart from a minor benefit for calcium channel blockers on stroke reduction that may arise from greater lowering of central blood pressure). The authors suggested that previous demonstrations of lack of efficacy of $\beta$-blockers on outcomes in previous analyses was due to lack of statistical power or to the use of atenolol. Other metaanalytic evidence suggested that the efficacy on outcomes was similar for different antihypertensive classes for equivalent decreases in blood pressure. ${ }^{68}$

The effects of the major antihypertensive classes on blood pressure and reductions in the risk of adverse cardiovascular outcomes appear to be similar in people with and without diabetes. ${ }^{69}$ 
Are There Clinically Relevant Differences Between Individual $\beta$-Blockers or Subtypes of $\beta$-Blockers with Regard to Management of Hypertension?

The phenomenon of sympathetic overdrive has received attention recently, with observations that the elevated sympathetic nervous activation can influence outcomes, particularly in younger, obese subjects or in smokers. ${ }^{70,71}$ Moreover, different antihypertensive drug classes may reduce sympathetic activation ( $\beta$-blockers, RAS blockers), have no effect (long-acting calcium channel blockers) or increase it (diuretics, short-acting calcium channel blockers). ${ }^{70}$ The use of $\beta$-blockade has been shown to be at least as effective as other antihypertensive agents for improving outcomes in younger hypertensive subjects. ${ }^{64}$ Smoking increases catecholamine levels markedly; in one study conducted four decades ago, administration of a non-selective $\beta$-blocker (propranolol) to healthy volunteers increased blood pressure during smoking, while a $\beta_{1-}$ selective agent (atenolol) did not. ${ }^{72}$ The inclusion of nonsmokers and smokers together in hypertension trials will potentially mask a greater effect of $\beta$-blockade on blood pressure in non-smokers. ${ }^{73}$

A $\beta$-blocker with additional $\alpha$-adrenoceptor blockade may provide additional suppression of sympatheticallymediated vasoconstriction, relative to a $\beta$-blocker without this property. ${ }^{74}$ Carvedilol represents the most well-known $\beta$-blocker with this property, but lacks $\beta_{1}$ selectivity (see above). High inter-individual variations in the pharmacokinetics of carvedilol (along with metoprolol, nebivolol and propranolol) have been observed, however, when compared with other $\beta$-blockers (bisoprolol, atenolol, sotalol, labetalol, nadolol, pindolol). ${ }^{75}$ It would be interesting to compare the clinical effects in hypertension of $\beta$-blockers with and without additional $\alpha$-blockade, where neither agent was potentially limited by complex pharmacokinetics.

\section{What the Guidelines Say}

There is divergence of recommendations for the management of uncomplicated hypertension among major guidelines. ${ }^{12,13}$ European guidance noted the results of recent meta-analyses that have, to a large extent, refuted earlier findings of a lack of efficacy with $\beta$-blockers compared with other therapies (see above), and has retained $\beta$-blockers among the five antihypertensive classes suitable for initiation of pharmacotherapy for the management of uncomplicated primary hypertension. The current US hypertension guideline does not include $\beta$-blockers among preferred first-line antihypertensive agents, citing less effect on damage to target organs vs renin-angiotensin system (RAS) blockers, tolerability issues, and smaller effect on stroke prevention, in particular. ${ }^{12}$

\section{Take-Home Messages: $\beta$-Blockers in Hypertension Management}

Recent large and well-designed meta-analyses, described above, have largely allayed concerns that $\beta$-blockers are less effective than other antihypertensive classes: these analyses have shown that blood pressure reduction per se is the main determinant of outcome in this population, with similar effects on outcomes between different antihypertensive drug classes. Nevertheless, the place of $\beta$-blockade in the management of primary hypertension has remained controversial, with important differences in recommendations for their use between major international guidelines. Guidelines agree on the place of $\beta$-blockers in the management of hypertension complicated by comorbid IHD or CHF.

\section{Potential for $\beta$-Blockade in the Management of Atrial Fibrillation}

Atrial fibrillation (AF) is the most common cardiac arrhythmia in Western countries, with a prevalence of about $1-4 \%$, and a somewhat lower prevalence of about $0.5-2 \%$ in Asia. ${ }^{76}$ The prevalence of AF is increasing in all age groups and in both genders. ${ }^{77}$ Population risk factors for $\mathrm{AF}$ include male gender, hypertension, valvular disease, diabetes, $\mathrm{MI}$ and $\mathrm{CHF} .{ }^{78}$ Perioperative $\mathrm{AF}$ is also a common complication of cardiac surgery. ${ }^{79}$ Even transient $\mathrm{AF}$ associated with a hospital procedure is a risk factor for subsequent stroke. ${ }^{80}$

Recent US guidelines support the use of $\beta$-blockade to slow the ventricular rate in patients with ACS who develop $\mathrm{AF}$, in the absence of contraindications to this treatment. ${ }^{81}$ The European Society of Cardiology supports the use of a $\beta$-blocker (preferably a cardioselective agent) as first-line pharmacologic therapy for people with stable HFrEF and AF. ${ }^{82}$ Finally, influential guidelines also support use of a $\beta$-blocker (not sotalol) as initial therapy for a patient indicated for pharmacological control of the ventricular rate in $\mathrm{AF}^{82,83}$

\section{Conclusions}

Selective $\beta_{1}$-adrenoceptor blockade remains an important cardiovascular therapy, with a strong evidence base for reducing the risk of adverse cardiovascular outcomes. 
Guidelines continue to disagree on the place of $\beta$-blockade within the first-line treatment of hypertension, although more recent meta-analyses suggest that the efficacy of antihypertensive treatments for preventing future cardiovascular events depends mostly on the magnitude of blood pressure reduction achieved rather than on the properties of individual classes of antihypertensive agents. The guidelines do agree that there continues to be a strong evidence base for the use of selective $\beta_{1}$ receptor blockers, especially without ISA, for the management of hypertension complicated by IHD or heart failure. There is no compelling evidence for a clinically relevant influence of differences in other properties of $\beta$-blockers, such as the degree of inverse agonism, lipophilicity etc., although this is hampered by a lack of head-to-head outcome trials between members of the $\beta$-blocker class.

\section{Acknowledgments}

A medical writer (Dr Mike Gwilt, GT Communications) funded by Merck Serono Middle East FZ-LLC) provided editorial assistance in the development of the manuscript. The authors retained full control over the content of the manuscript.

\section{Disclosure}

AP reports personal fees, non-financial andsupport for attendiance at international congresses from Merck Serono Middle East FZ-LLC, Menarini, and Bouchara-Recordati SAS. SM is an employee of Merck Serono Middle East FZ-LLC, an affiliate of Merck KGaA, Germany. The authors report no other conflicts of interest in this work.

\section{References}

1. Cruickshank JM. Are we misunderstanding beta-blockers. Int J Cardiol. 2007;120(1):10-27. doi:10.1016/j.ijcard.2007.01.069

2. Khilnani G, Khilnani AK. Inverse agonism and its therapeutic significance. Indian J Pharmacol. 2011;43(5):492-501. doi:10.4103/ 0253-7613.84947

3. Bond RA, Lucero Garcia-Rojas EY, Hegde A, Walker JKL. Therapeutic potential of targeting B-arrestin. Front Pharmacol. 2019;10:124. doi:10.3389/fphar.2019.00124

4. Metra M, Torp-Pedersen C, Swedberg K, et al. Influence of heart rate, blood pressure, and beta-blocker dose on outcome and the differences in outcome between carvedilol and metoprolol tartrate in patients with chronic heart failure: results from the COMET trial. Eur Heart $J$. 2005;26(21):2259-2268. doi:10.1093/eurheartj/ehi386

5. Baker JG. The selectivity of $\beta$-adrenoceptor antagonists at the human $\beta 1, \beta 2$ and $\beta 3$ adrenoceptors. Br J Pharmacol. 2005;144(3):317-322. doi:10.1038/sj.bjp. 0706048

6. Fonseca VA. Effects of beta-blockers on glucose and lipid metabolism. Curr Med Res Opin. 2010;26(3):615-629. doi:10.1185/ 03007990903533681
7. Hirst JA, Farmer AJ, Feakins BG, Aronson JK, Stevens RJ. Quantifying the effects of diuretics and $\beta$-adrenoceptor blockers on glycaemic control in diabetes mellitus - a systematic review and meta-analysis. $\mathrm{Br}$ J Clin Pharmacol. 2015;79(5):733-743. doi:10.1111/bcp.12543

8. Barron AJ, Zaman N, Cole GD, Wensel R, Okonko DO, Francis DP. Systematic review of genuine versus spurious side-effects of beta-blockers in heart failure using placebo control: recommendations for patient information. Int J Cardiol. 2013;168(4):3572-3579. doi:10.1016/j.ijcard.2013.05.068

9. Shen L, Shah BR, Reyes EM, et al. Role of diuretics, $\beta$ blockers, and statins in increasing the risk of diabetes in patients with impaired glucose tolerance: reanalysis of data from the NAVIGATOR study. BMJ. 2013;347(dec09 7):f6745. doi:10.1136/bmj.f6745

10. Lehtonen A. Effect of beta blockers on blood lipid profile. Am Heart J. 1985;109(5):1192-1196. doi:10.1016/0002-8703(85)90707-0

11. National Institute for Health and Care Excellence. Bisoprolol fumarate. Available from: https://bnf.nice.org.uk/drug/bisoprololfumarate.html\#sideEffects. Accessed October, 2020.

12. Whelton PK, Carey RM, Aronow WS, et al. 2017 ACC/AHA/AAPA/ $\mathrm{ABC} / \mathrm{ACPM} / \mathrm{AGS} / \mathrm{APhA} / \mathrm{ASH} / \mathrm{ASPC} / \mathrm{NMA} / \mathrm{PCNA}$ guideline for the prevention, detection, evaluation, and management of high blood pressure in adults: a report of the American college of cardiology/ American heart association task force on clinical practice guidelines. Hypertension. 2017.

13. Williams B, Mancia G, Spiering W, et al. 2018 ESC/ESH guidelines for the management of arterial hypertension. Eur Heart $J$. 2018;39:3021-3104.

14. Andell P, Erlinge D, Smith JG, et al. $\beta$-blocker use and mortality in COPD patients after myocardial infarction: a Swedish Nationwide Observational Study. J Am Heart Assoc. 2015;4(4):e001611. doi:10.1161/JAHA.114.001611

15. Lainscak M, Podbregar M, Kovacic D, Rozman J, von Haehling S. Differences between bisoprolol and carvedilol in patients with chronic heart failure and chronic obstructive pulmonary disease: a randomized trial. Respir Med. 2011;105(Suppl 1):S44-9. doi:10.1016/S0954-6111(11)70010-5

16. Kubota Y, Asai K, Furuse E, et al. Impact of $\beta$-blocker selectivity on long-term outcomes in congestive heart failure patients with chronic obstructive pulmonary disease. Int J Chron Obstruct Pulmon Dis. 2015;10:515-523. doi:10.2147/COPD.S79942

17. Farzam K. Beta blockers. Stat pearls [Internet]. Available from: https://www.statpearls.com/ArticleLibrary/viewarticle/18241. Accessed March, 2021.

18. Rozec B, Erfanian M, Laurent K, Trochu J-N, Gauthier C. Nebivolol, a vasodilating selective $\beta 1$-blocker, is a $\beta 3$-adrenoceptor agonist in the nonfailing transplanted human heart. $J$ Am Coll Cardiol. 2009;53 (17):1532-1538. doi:10.1016/j.jacc.2008.11.057

19. Poirier L, Tobe SW. Contemporary use of $\beta$-blockers: clinical relevance of subclassification. Can J Cardiol. 2014;30(5 Suppl):S9-S15. doi:10.1016/j.cjca.2013.12.001

20. Albouaini K, Andron M, Alahmar A, Egred M. Beta-blockers use in patients with chronic obstructive pulmonary disease and concomitant cardiovascular conditions. Int J Chron Obstruct Pulmon Dis. 2007;2 (4):535-540.

21. Lim KP, Loughrey S, Musk M, Lavender M, Wrobel JP. Beta-blocker under-use in COPD patients. Int $J$ Chron Obstruct Pulmon Dis. 2017;12:3041-3046. doi:10.2147/COPD.S144333

22. Wai B, Kearney LG, Hare DL, Ord M, Burrell LM, Srivastava PM. Beta blocker use in subjects with type 2 diabetes mellitus and systolic heart failure does not worsen glycaemic control. Cardiovasc Diabetol. 2012;11(1):14. doi:10.1186/1475-2840-11-14

23. Zhang X, Shen C, Zhai S, Liu Y, Yue WW, Han L. A metaanalysis of the effects of $\beta$-adrenergic blockers in chronic heart failure. Exp Ther Med. 2016;12(4):2489-2496. doi:10.3892/ etm.2016.3657 
24. CIBIS Investigators and Committees. A randomized trial of beta-blockade in heart failure. The Cardiac Insufficiency Bisoprolol Study (CIBIS). Circulation. 1994;90(4):1765-1773. doi:10.1161/01. CIR.90.4.1765

25. CIBIS Investigators. The Cardiac Insufficiency Bisoprolol Study II (CIBIS-II): a randomised trial. Lancet. 1999;353(9146):9-13. doi:10.1016/S0140-6736(98)11181-9

26. Willenheimer R, van Veldhuisen D, Silke B, et al. Effect on survival and hospitalization of initiating treatment for chronic heart failure with bisoprolol followed by enalapril, as compared with the opposite sequence: results of the randomized Cardiac Insufficiency Bisoprolol Study (CIBIS) III. Circulation. 2005;112(16):2426-2435. doi:10.1161/ CIRCULATIONAHA.105.582320

27. MERIT-HF Investigators. Effect of metoprolol $\mathrm{CR} / \mathrm{XL}$ in chronic heart failure: metoprolol $\mathrm{CR} / \mathrm{XL}$ randomised intervention trial in congestive heart failure (MERIT-HF). Lancet. 1999;353 (9169):2001-2007. doi:10.1016/S0140-6736(99)04440-2

28. Flather MD, Shibata MC, Coats AJ, et al. Randomized trial to determine the effect of nebivolol on mortality and cardiovascular hospital admission in elderly patients with heart failure (SENIORS). Eur Heart J. 2005;26(3):215-225. doi:10.1093/eurheartj/ehi115

29. Beta-Blocker Evaluation of Survival Trial Investigators. A trial of the betablocker bucindolol in patients with advanced chronic heart failure. $N$ Engl J Med. 2001;344(22):1659-1667. doi:10.1056/ NEJM200105313442202

30. Packer M, Bristow MR, Cohn JN, et al. The effect of carvedilol on morbidity and mortality in patients with chronic heart failure. US Carvedilol Heart Failure Study Group. $N$ Engl J Med. 1996;334 (21):1349-1355. doi:10.1056/NEJM199605233342101

31. Packer M, Coats AJS, Fowler MB, et al. Effect of carvedilol on survival in severe chronic heart failure. $N$ Engl J Med. 2001;344 (22):1651-1658. doi:10.1056/NEJM200105313442201

32. Bonet S, Agustí A, Arnau JM, et al. Beta-adrenergic blocking agents in heart failure: benefits of vasodilating and non-vasodilating agents according to patients' characteristics: a meta-analysis of clinical trials. Arch Intern Med. 2000;160(5):621-627. doi:10.1001/archinte.160.5.621

33. Chatterjee S, Biondi-Zoccai G, Abbate A, et al. Benefits of $\beta$ blockers in patients with heart failure and reduced ejection fraction: network meta-analysis. BMJ. 2013;346(jan16 1):f55. doi:10.1136/ bmj.f55

34. Kotecha D, Manzano L, Krum H, et al.Effect of age and sex on efficacy and tolerability of $\beta$ blockers in patients with heart failure with reduced ejection fraction: individual patient data meta-analysis. BMJ. 2016;353:11855.

35. Hoes AW. $\beta$ blockers for heart failure. BMJ. 2016;353:i2074. doi:10.1136/bmj.i2074

36. Lam PH, Gupta N, Dooley DJ, et al. Role of high-dose beta-blockers in patients with heart failure with preserved ejection fraction and elevated heart rate. Am J Med. 2018;131(12):1473-1481. doi:10.1016/j. amjmed.2018.07.008

37. Zheng SL, Chan FT, Nabeebaccus AA, et al. Drug treatment effects on outcomes in heart failure with preserved ejection fraction: a systematic review and meta-analysis. Heart. 2018;104 (5):407-415. doi:10.1136/heartjnl-2017-311652

38. Cleland JGF, Bunting KV, Flather MD, et al. Beta-blockers for heart failure with reduced, mid-range, and preserved ejection fraction: an individual patient-level analysis of double-blind randomized trials. Eur Heart J. 2018;39(1):26-35. doi:10.1093/eurheartj/ehx564

39. Tsujimoto T, Kajio H. Beta-blocker use and cardiovascular event risk in patients with heart failure with preserved ejection fraction. Sci Rep. 2018;8(1):9556. doi:10.1038/s41598-018-27799-y

40. Persson H, Rythe'n-Alder E, Melcher A, Erhardt L. Effects of beta receptor antagonists in patients with clinical evidence of heart failure after myocardial infarction: double blind comparison of metoprolol and xamoterol. Br Heart J. 1995;74(2):140-148. doi:10.1136/hrt.74.2.140
41. Yancy CW, Jessup M, Bozkurt B, et al. 2017 ACC/AHA/HFSA focused update of the $2013 \mathrm{ACCF} / \mathrm{AHA}$ guideline for the management of heart failure: a report of the American college of cardiology/ American heart association task force on clinical practice guidelines and the heart failure society of America. Circulation. 2017;136(6): e137-e161. doi:10.1161/CIR.0000000000000509

42. Ponikowski P, Voors AA, Anker SD, et al. 2016 ESC guidelines for the diagnosis and treatment of acute and chronic heart failure: the task force for the diagnosis and treatment of acute and chronic heart failure of the European Society of Cardiology (ESC) developed with the special contribution of the Heart Failure Association (HFA) of the ESC. Eur Heart J. 2016;37(27):2129-2200. doi:10.1093/eurheartj/ehw128

43. Freemantle N, Cleland J, Young P, Mason J, Harrison J. Beta blockade after myocardial infarction: systematic review and meta regression analysis. BMJ. 1999;318(7200):1730-1737. doi:10.1136/ bmj.318.7200.1730

44. Andreasen C, Andersson C. Current use of beta-blockers in patients with coronary artery disease. Trends Cardiovasc Med. 2018;28 (6):382-389. doi:10.1016/j.tcm.2017.12.014

45. Peyracchia M, Errigo D, Raposeiras Rubin S, et al. Beta-blocker therapy reduces mortality in patients with coronary artery disease treated with percutaneous revascularization: a meta-analysis of adjusted results. J Cardiovasc Med (Hagerstown). 2018;19 (7):337-343. doi:10.2459/JCM.0000000000000662

46. Andersson C, Shilane D, Go AS, et al. $\beta$-blocker therapy and cardiac events among patients with newly diagnosed coronary heart disease. $J \mathrm{Am}$ Coll Cardiol. 2014;64(3):247-252. doi:10.1016/j.jacc.2014.04.042

47. Sorbets E, Steg PG, Young R, et al. $\beta$-blockers, calcium antagonists, and mortality in stable coronary artery disease: an international cohort study. Eur Heart J. 2018. doi:10.1093/eurheartj/ehy811

48. Von Arnim T. Prognostic significance of transient ischemic episodes: response to treatment shows improved prognosis. results of the Total Ischemic Burden Bisoprolol Study (TIBBs) follow-up. J Am Coll Cardiol. 1996;28(1):20-24. doi:10.1016/0735-1097(96)00122-2

49. von Arnim T. Medical treatment to reduce total ischemic burden: total ischemic burden bisoprolol study (TIBBS), a multicenter trial comparing bisoprolol and nifedipine. The TIBBS investigators. $J$ Am Coll Cardiol. 1995;25(1):231-238. doi:10.1016/0735-1097(94)00345-Q

50. Brugts JJ, Bertrand M, Remme W, et al. The treatment effect of an ace-inhibitor based regimen with perindopril in relation to beta-blocker use in 29,463 patients with vascular disease: a combined analysis of individual data of ADVANCE, EUROPA and PROGRESS trials. Cardiovasc Drugs Ther. 2017;31 (4):391-400. doi:10.1007/s10557-017-6747-9

51. Seo GW, Kim DK, Kim KH, et al. Impact of carvedilol versus $\beta 1$-selective $\beta$ blockers (bisoprolol, metoprolol, and nebivolol) in patients with acute myocardial infarction undergoing percutaneous coronary intervention. Am J Cardiol. 2015;116(10):1502-1508. doi:10.1016/j.amjcard.2015.08.013

52. Roffi M, Patrono C, Collet JP, et al. 2015 ESC Guidelines for the management of acute coronary syndromes in patients presenting without persistent ST-segment elevation: task force for the management of acute coronary syndromes in patients presenting without persistent ST-segment elevation of the European Society of Cardiology (ESC). Eur Heart J. 2016;37 (3):267-315. doi:10.1093/eurheartj/ehv320

53. Ibanez B, James S, Agewall S, et al. 2017 ESC guidelines for the management of acute myocardial infarction in patients presenting with ST-segment elevation: the task force for the management of acute myocardial infarction in patients presenting with ST-segment elevation of the European Society of Cardiology (ESC). Eur Heart J. 2018;39(2):119-177. doi:10.1093/eurheartj/ehx393

54. O'Gara PT, Kushner FG, Ascheim DD, et al. 2013 ACCF/AHA guideline for the management of ST-elevation myocardial infarction: a report of the American college of cardiology foundation/American heart association task force on practice guidelines. Circulation. 2013;127(4):e362-425. doi:10.1161/CIR.0b013e3182742c84 
55. Amsterdam EA, Wenger NK, Brindis RG, et al. 2014 AHA/ACC guideline for the management of patients with non-ST-elevation acute coronary syndromes: a report of the American college of cardiology/American heart association task force on practice guidelines. Circulation. 2014;130 (25):e344-426. doi:10.1161/CIR.0000000000000134

56. Fihn SD, Gardin JM, Abrams J, et al. 2012 ACCF/AHA/ACP/AATS/ PCNA/SCAI/STS guideline for the diagnosis and management of patients with stable ischemic heart disease: a report of the American college of cardiology foundation/American heart association task force on practice guidelines, and the American college of physicians, American association for thoracic surgery, preventive cardiovascular nurses association, society for cardiovascular angiography and interventions, and society of thoracic surgeons. $J$ Am Coll Cardiol. 2012;60(24):e44-e164. doi:10.1016/j.jacc.2012.07.013

57. Knuuti J, Wijns W, Saraste A, et al. 2019 ESC guidelines for the diagnosis and management of chronic coronary syndromes. Eur Heart J. 2020;41:407-477.

58. Isted A, Williams R, Oakeshott P. Secondary prevention following myocardial infarction: a clinical update. Br J Gen Pract. 2018;68 (668):151-152. doi:10.3399/bjgp18X695261

59. Goldberger JJ, Bonow RO, Cuffe M, et al. Effect of beta-blocker dose on survival after acute myocardial infarction. $\mathrm{J} \mathrm{Am} \mathrm{Coll} \mathrm{Cardiol}$. 2015;66(13):1431-1441. doi:10.1016/j.jacc.2015.07.047

60. Kotecha D, Flather MD, Altman DG, et al. Heart rate and rhythm and the benefit of beta-blockers in patients with heart failure. $J$ Am Coll Cardiol. 2017;69(24):2885-2896. doi:10.1016/j.jacc.2017.04.001

61. Yancy CW, Januzzi JL Jr, Allen LA, et al. 2017 ACC expert consensus decision pathway for optimization of heart failure treatment: answers to 10 pivotal issues about heart failure with reduced ejection fraction: a report of the american college of cardiology task force on expert consensus decision pathways. J Am Coll Cardiol. 2018;71 (2):201-230. doi:10.1016/j.jacc.2017.11.025

62. Wiysonge CS, Bradley HA, Volmink J, Mayosi BM, Opie LH. Betablockers for hypertension. Cochrane Database Syst Rev. 2017;1: CD002003. doi:10.1002/14651858.CD002003.pub5

63. Lindholm LH, Carlberg B, Samuelsson O. Should beta blockers remain first choice in the treatment of primary hypertension? A meta-analysis. Lancet. 2005;366(9496):1545-1553. doi:10.1016/ S0140-6736(05)67573-3

64. Khan N, McAlister FA. Re-examining the efficacy of beta-blockers for the treatment of hypertension: a meta-analysis. CMAJ. 2006;174 (12):1737-1742. doi:10.1503/cmaj.060110

65. Grossman E, Goldbourt U. Meta-analyses of antihypertensive therapy: are some of them misleading? Curr Hypertens Rep. 2001;3 (5):381-386. doi:10.1007/s11906-001-0054-2

66. Khan N, McAlister FA. Do beta-blockers have a role in treating hypertension? Yes. Can Fam Physician. 2007;53(4):614-621.

67. Law MR, Morris JK, Wald NJ. Use of blood pressure lowering drugs in the prevention of cardiovascular disease: meta-analysis of 147 randomised trials in the context of expectations from prospective epidemiological studies. BMJ. 2009;338(may19 1):b1665. doi:10.1136/bmj.b1665

68. Thomopoulos C, Parati G, Zanchetti A, et al. Effects of blood pressure-lowering on outcome incidence in hypertension: 5. Head-tohead comparisons of various classes of antihypertensive drugs overview and meta-analyses. J Hypertens. 2015;33(7):1321-1341. doi:10.1097/HJH.0000000000000614
69. Turnbull F, Neal B, Algert C, et al. Effects of different blood pressure-lowering regimens on major cardiovascular events in individuals with and without diabetes mellitus: results of prospectively designed overviews of randomized trials. Arch Intern Med. 2005;165:1410-1419.

70. Grassi G. Sympathetic overdrive in hypertension: clinical and therapeutic relevance. An article from the e-journal of the ESC council for cardiology practice. Eur Soc Cardiol. 2015;13:6-24.

71. Santilli F, Simeone P, D'Ardes D, Davì G. The deadly line linking sympathetic overdrive, dipping status and vascular risk: critical appraisal and therapeutic implications. Hypertens Res. 2016;39 (6):404-406. doi:10.1038/hr.2016.27

72. Trap-Jensen J, Carlsen JE, Svendsen TL, Christensen NJ. Cardiovascular and adrenergic effects of cigarette smoking during immediate non-selective and selective beta adrenoceptor blockade in humans. Eur J Clin Invest. 1979;9(3):181-183. doi:10.1111/j.13652362.1979.tb00920.x

73. Cruickshank JM. Beta-blockers in the treatment of hypertension. BMJ. 2009;338.

74. Bloom HL, Vinik AI, Colombo J. Differential effects of adrenergic antagonists (carvedilol vs metoprolol) on parasympathetic and sympathetic activity: a comparison of clinical results. Heart Int. 2014;9 (1):15-21. doi:10.5301/HEART.2014.12496

75. Ågesen FN, Weeke PE, Tfelt-Hansen P, Tfelt-Hansen J;. Pharmacokinetic variability of beta-adrenergic blocking agents used in cardiology. Pharmacol Res Perspect. 2019;7(4):e00496. doi:10.1002/prp2.496

76. Zulkifly H, Lip GYH, Lane DA, et al. Epidemiology of atrial fibrillation. Int J Clin Pract. 2018;72(3):e13070. doi:10.1111/ijcp.13070

77. Adderley NJ, Ryan R, Nirantharakumar K, Marshall T. Prevalence and treatment of atrial fibrillation in UK general practice from 2000 to 2016. Heart. 2019;105(1):27-33. doi:10.1136/heartjnl-2018-312977

78. Benjamin EJ, Levy D, Vaziri SM, D’Agostino RB, Belanger AJ, Wolf PA. Independent risk factors for atrial fibrillation in a population-based cohort. The Framingham Heart Study. JAMA. 1994;271(11):840-844. doi:10.1001/jama.1994.03510350050036

79. Banach M, Rysz J, Drozdz JA, et al. Risk factors of atrial fibrillation following coronary artery bypass grafting: a preliminary report. Circ J. 2006;70(4):438-441. doi:10.1253/circj.70.438

80. Megens MR, Churilov L, Thijs V, et al. New-onset atrial fibrillation after coronary artery bypass graft and long-term risk of stroke: a meta-analysis. $J$ Am Heart Assoc. 2017;6(12):e007558. doi:10.1161/JAHA.117.007558

81. January CT, Wann LS, Calkins H, et al. 2019 AHA/ACC/HRs focused update of the 2014 AHA/ACC/HRS guideline for the management of patients with atrial fibrillation: a report of the American college of cardiology/American heart association task force on clinical practice guidelines and the heart rhythm society. $\mathrm{J}$ Am Coll Cardiol. 2019;74(1):104-132. doi:10.1016/j.jacc.2019.01.011

82. Kirchhof P, Benussi S, Kotecha D, et al. 2016 ESC guidelines for the management of atrial fibrillation developed in collaboration with EACTS. Eur Heart J. 2016;37:2893-2962.

83. National Institute for health and Care Excellence. Atrial fibrillation: management. Clinical guideline [CG180]; June 2014. Available from: https:// www.nice.org.uk/guidance/cg180/chapter/1-Recommendations\#rate-and -rhythm-control. Accessed October, 2020. 


\section{Publish your work in this journal}

Vascular Health and Risk Management is an international, peerreviewed journal of therapeutics and risk management, focusing on concise rapid reporting of clinical studies on the processes involved in the maintenance of vascular health; the monitoring, prevention and treatment of vascular disease and its sequelae; and the involvement of metabolic disorders, particularly diabetes. This journal is indexed on PubMed Central and MedLine. The manuscript management system is completely online and includes a very quick and fair peerreview system, which is all easy to use. Visit http://www.dovepress. com/testimonials.php to read real quotes from published authors. 